\title{
Struggling Through Money: Local Banknotes of Republic of Indonesia During the Independence Revolution in the Residency of Lampung
}

\author{
Rinaldo Adi Pratama \\ History Education \\ Lampung University \\ Lampung, Indonesia \\ rinaldo@fkip.unila.ac.id
}

\author{
Maskun Maskun \\ History Education \\ Lampung University \\ Lampung, Indonesia \\ maskun.1959@fkip.unila.ac.id
}

\author{
Ali Imron \\ History Education \\ Lampung University \\ Lampung, Indonesia \\ ali.imron@fkip.unila.ac.id
}

\begin{abstract}
Money function during the revolution in Lampung Residency was not limited to its traditional function as an economic transaction, but also as a media of struggle in defending the sovereignty of Indonesia. This research focuses on exploring information related to events that occurred during the revolution in the Lampung Residency, especially in the monetary sector, namely the Local Banknotes of the Republic of Indonesia or ORIDA. The research uses a historical method that includes heuristics, source critic, interpretation, and the last stage is historiography. The results showed that the Lampung Residency during the independence revolution issued a monetary policy, independent from the Government of the Province of Sumatra and the Government of the Republic of Indonesia. This policy issued by the acting resident Gele Harun Nasution and Regent Akhmad Akuan aims to maintain the existence of the Lampung Residency as part of the sovereign Indonesian government. The acting resident issued the local banknotes that are only valid in several areas in Lampung with varying nominal. The monetary policy issued by the Resident of Lampung in Tanjungkarang-Telukbetung and Regent of North Lampung Regency in Kotabumi made the Lampung residency free from the economic and political crisis and the Dutch were unable to control the Lampung Residency region during their military aggression in 1947-1949.
\end{abstract}

Keywords-Lampung residency, independence revolution, local banknotes, Indonesia

\section{INTRODUCTION}

Talking about money, of course, money has a vital function and a position for a country. Money is an essential instrument in every country in the economic sector, namely a means of transactions to store wealth. In addition, politically, money has a role as an instrument of struggle, affirmation of authority, and symbol of the sovereignty of a nation [1].

For the Indonesian context, the political function of money was once really felt important as an instrument of the struggle to maintain independence while asserting sovereignty [2]. It is recorded in the history of the nation's struggle to overcome the economic blockade carried out by the Dutch army during the independence revolution. The struggle began from efforts to keep the money that became the main driver for economic life can continue to be printed and circulated until supporting financing for logistics needs and combat equipment for fighters on the battlefield to fight the first and second Dutch Military Aggression.

After Japan surrendered to the allies in August 1945, Indonesia proclaimed its independence on August 17, 1945. At that time, Indonesia's economic conditions have not improved markedly by soaring prices everywhere and beyond the reach of people's purchasing power. At the beginning of independence, there were three types of currency in Indonesia and it make high inflation, including in the Lampung Residency.

First, De Javasche Bank (DJB) money printed by De Javasche Bank. Second, Dutch East Indies money was printed by the Dutch East Indies government. Third, invasion money or Japanese rupiah printed by Syomin Ginko and Dai Nippon soldiers. The three types of currencies in circulation became one of the factors of economic turmoil left by Japan and had to be addressed by the Indonesian government, which had just gained independence [3]. 
During the revolution era, the Japanese currency is still valid in Indonesia as a legal means of payment. Nevertheless, the former money of the Dutch East Indies Government is still widely circulated among the public. To overcome this, Mohammad Hatta as Vice President said that the Government of Indonesia would soon issue a currency as a legal means of payment, namely the money of the Republic of Indonesia or Orang Republik Indonesia (ORI). The currency would be one of the proper weapons to prevent economic blockade by the Dutch from causing economic chaos. On October 24, 1945, a meeting was held that discussed money printing in the Banteng field and was chaired by the Minister of Finance, Mr. A.A. Maramis of the First Cabinet of the Republic of Indonesia.

Towards the end of October 1946, fourteen months after the Proclamation of Independence. The official currency of the government of Indonesia issued. Even in ORI currency is listed the date of emissions is October 17, 1945. History records that October 30, 1946, was the beginning of the history of the issuance of the currency of the Republic of Indonesia, which was later even designated as Financial Day.

That shows the length of the process that must be taken in preparing the issuance of ORI as one of the Indonesian identities. At that time, Vice President of the Republic of Indonesia Mohammad Hatta gave a speech in front of the Radio of the Republic of Indonesia in Yogyakarta to announce the birth of banknotes that replaced De Javasche Bank money.

The Dutch occupation and economic blockade caused difficulty in the circulation of money throughout the Republic of Indonesia. At that time, Indonesia based in Yogyakarta was experiencing a precarious time due to impossible situations, including ORI printing. In addition, ORI has not been able to reach all regions of Indonesia. Therefore, it is necessary to take steps so that the needs of payment instruments in these regions can still be met so that economic activities are not hampered. The emergency money printed by the several areas was called Local Banknotes of the Republic of Indonesia (ORIDA) [4].

Due to the widespread Dutch occupation, poor communication between the central government in Yogjakarta and another region, also the money supply between the center and the region became cut off. The expenditure of money was thus settled by provincial, residency, and even district governments during the 1947-1949 war of independence. Due to the first Dutch Military Aggression, the printing of ORIPS on March 31, 1947, in Pematang Siantar had to be moved to Bukittinggi because the Dutch controlled Pematang Siantar. As a result, the Provincial Government can no longer afford to supply the money for government spending. ORIPS was also unable to reach all areas of Sumatra including the Lampung Residency.
Facing such an uncertain situation, the Resident of Lampung has requested the approval of the Governor of Sumatra to be allowed to print its own money for the needs in the Lampung Residency area. The people of Lampung feel proud because in the past the Lampung area was trusted by the central government to print its currency. The Governor agreed and gave power to the Lampung Residency to print the ORIDA of the Lampung Residency version.

The resident and regent sign all money printed by Lampung Residency before being distributed. ORIDA of Lampung Residency occurs due to various obstacles experienced by the government in distributing ORI and ORIPS so that many areas in South Sumatra including Lampung Residency are printing their own money to meet the needs of the region. Therefore, it is interesting to study how the struggle at the local level, namely in South Sumatra, especially in the Lampung Residency region about the struggle of the nation who use money as an instrument in supporting the continuity of the republic in controlling the economy to safeguard the sovereignty of the Republic of Indonesia.

\section{LITERATURE REVIEW}

\section{A. Lampung Residency}

The residency was an administrative division in a province during the Dutch East Indies and continued until Indonesia became independent until the 1950s. The terms of residency come from the Dutch Residentie, which means a resident head. During the Dutch colonial era, a resident became the supreme colonial ruler while representing the Governor-General of the Dutch East Indies in his domain. The resident also became a representative of the Dutch East Indies Government in his residency with legislative, executive, and judicial powers in his hands. Thus, the power of a resident is absolute and infinite.

A residency consists of several afdeeling (districts). However, not all provinces in Indonesia ever formed residency. Only on the islands of Java, Sumatra, Kalimantan, Bali, Lombok and Sulawesi. The history of residency continued until the Japanese occupation. During this time, the provincial government was abolished so that residency (syu in Japanese) became the highest administrative part of the Dutch East Indies of Japan [5], [6]. After independence, the administrative division of residency was still inherited. The residency has its own House of Representatives. The right to residency autonomy was revoked in 1948, but residency remained an administrative part of the government [7].

Lampung Province was established on March 18, 1964, based on the enactment of Government Regulation No. 3/1964, which later became Law No. 14 of 1964, inseparable from the history of Lampung 
Residency. Before the Lampung region became a province, Lampung province is currently a residency incorporated with the Province of South Sumatra.

Lampung Residency has existed since Lampung has not been its province, which at that time Lampung was divided from onder afdelling which each headed by Controlleur was held by the Dutch. The resident is located in Tanjungkarang-Telukbetung. The division of Indonesian territory into Residency has existed since the Dutch colonial era, first divided into several residencies in Java Island.

After proclaiming Indonesia's independence on August 17, 1945, Lampung Residency was merged into Sumatra Province based on the determination letter of the Preparatory Committee for Indonesian Independence (PPKI) dated August 19, 1945, namely about the division of the Republic of Indonesia into eight provinces, namely: Sumatra, West Java, Central Java, East Java, Sunda Kecil, Maluku, Sulawesi, and Kalimantan. Each province carries several residencies and each Residency is further divided into several districts/municipalities. As is the case in Java Island, gradually in each region of Sumatra established a Regional National Committee whose position is regulated through the Governor of Sumatra Information dated April 12, 1946, No. 2 / MGS, according to Law No 1 of 1945 [8].

Still on the same day, on April 12, 1946, the Governor of North Sumatra Mr. Teuku Muhammad Hasan issued Regulation No. 8/MGS containing provisional regulations on the Indonesian National Committee (KNI) in Sumatra. KNI in the region is used as the Regional People's Representative Council (DPRD). The name is adjusted to the name of each region, for example, the DPRD Aceh, DPRD Riau, and DPR Lampung.

Each sub-province is led by a Junior Governor who coordinates the Residency and government positions in the regions. The Government of North Sumatra was carried out following the information of the Governor of North Sumatra on August 30, 1946, which stated that the provincial government was adapted to the central government.

The leadership of the Young Governor in each sub-province continues as an administrative region that in practice regulates their respective households so that the province of North Sumatra seems to consist of 3 provinces. However, in 1948, the Province of Sumatra has divided into several areas. Lampung Residency became part of South Sumatra Province based on Law No. 10 of 1948 concerning the Division of Sumatra in Three Provinces consisting of North Sumatra Province, including the Residency of Aceh, East Sumatra, and Tapanuli. Central Sumatra Province, which includes the Residency of West Sumatra, Riau, and Jambi. Province of South Sumatra, which includes the Residency of Bengkulu, Palembang, Lampung, and Bangka Belitung.

To follow up on the decision, Governor of Sumatra Mr. Teuku Muhammad Hasan appointed Palembang Resident Dr A.K. Gani as The Young Governor of South Sumatra, his domain includes the residency areas of Palembang, Lampung, Bengkulu and Bangka Belitung. At the same time, West Sumatra Resident Dr. Muhamamd Djamil was appointed as the Young Governor of Central Sumatra. His government area includes the residency of West Sumatra, Riau, and Jambi. Meanwhile, the Head of Aceh Resident Justice Office Mr. S. M. Amin was appointed as the Young Governor of North Sumatra. His government areas include the residential areas of Aceh, East Sumatra, and Tapanuli.

\section{B. Local Banknotes of Republic of Indonesia (ORIDA)}

After the proclamation of Indonesian Independence proclaimed on August 17, 1945, by Sukarno-Hatta in Jakarta, the newly established government of the Republic of Indonesia did not yet have its currency as a symbol of state sovereignty lasted until 1946. On October 30, 1946, the ORI was published [9]-[11]. ORI appears in a one-cent coin with the face look of the kris drawn and a back image of the text of the law.

To improve the economy and finance the war against Dutch forces, the Republic of the Republic then issued a policy by circulating the ORI officially enacted on October 30, 1946. The spread of ORI throughout the territory of The Republic of Indonesia experienced many obstacles, especially after the Dutch first aggression in 1947 [12] [13].

ORI is the first currency for the Republic of Indonesia as well as a means for struggle. Money that has an economic value used as a means of exchange, storage of value, units of calculation, and the size of delayed payments has other functions. During the revolution, money also functioned as a unifying tool, plaintiff of a sense of nationalism, and showed a sovereign Indonesia in the world's eyes. Money has economic value, the money also serves as a means of politics and struggle in the territory of Indonesia.

ORI circulated by the central government reached all regions of Indonesia due to the difficulty of transportation and economic blockade by NICA. To meet the needs of money in the region, the Indonesian government then authorizes each region to print its own money. This money is known as the Local Banknotes of the Republic of Indonesia (ORIDA).

ORIDA is one of the policies of the Government of the Republic of Indonesia in addressing the country's finances and maintaining people's trust in the State of Indonesia at the beginning of independence. As a result of the Dutch economic blockade, ORI could not 
reach Sumatra island and other places. To meet the needs of money in the region and a symbol of economic struggle against NICA money, in Sumatra circulated many types of ORIDA including in Lampung residency that issued its own ORIDA as a form of struggle against the Dutch.

Some types of ORIDA circulating on Sumatra other than ORIDA Lampung Residency include ORIPS (Money of the Republic of Indonesia Sumatra Province), ORIPSU (Money of the Republic of Indonesia North Sumatra), URITA (Money of the Republic of Indonesia Tapanuli), Mandate of the Palembang Regional Defense Council (DPDP), Valid Payment Mark valid for South Sumatra [14].

The use of ORI and ORIDA throughout Indonesia lasted until 1949. At the end of this year, a Round Table Conference (KMB) was held in The Hague, officially ending the Indonesia-Netherlands conflict. In the economic sector, it was agreed that DJB was appointed as the circulation bank of the United States of Indonesia (RIS). Based on the decision, the money applicable in Indonesia is RIS currency printed and circulated by DJB [15]. Therefore, in early 1950, ORI was withdrawn from circulation. Similarly, various types of ORIDA are scattered in these areas as the applicable money is RIS money.

However, the circulation of ORI is very limited and does not cover the entire territory of the Republic of Indonesia. In Sumatra, the rupiah is widely circulated in Japan [16]. In the circulation of the Japanese currency too much in the community, the value continues to decline. On the contrary, the prices of goods continue to soar. One of the causes of Japanese currency inflation turned out to be the work of the Dutch government. It is commonly known that the British Government in Singapore had obtained the cliché to print the money and then the tools fell into Dutch hands. With that tool, finally, the Dutch can spread counterfeit money to the territory of the Republic.

To solve the problem, the Governor of Sumatra Province, Mr. Teuku Muhammad Hasan issued Information No. 20 /MGS dated December 2, 1946, which announced the enactment of ORI as a valid exchange rate of 1 ORI rupiah equal to 100 rupiahs of Japanese money [17].

However, the steps taken by the Governor of Sumatra were not able to overcome the financial problems of the Sumatra provincial government. In early 1947 the budget for employee salaries and struggle costs was not met. State coffers are not enough to meet government spending needs. Attempts to request assistance to the Central Government to send ORI were also unsuccessful. As a result, Mr. Teuku Muhammad Hasan as governor of Sumatra and Deputy of the Central Government in Sumatra, requested the consideration of the Minister of Finance of the Republic of Indonesia, Mr. Syafruddin Prawiranegara, so that the Provincial Government of Sumatra could print its own money.

In American history, money was used as a medium of struggle in war conditions during the struggle for independence of the United States (1775-1783) when it was colonized by the British. At that time, the struggle for independence published the colony's money that the American Congress authorized. With the colony's money, all the costs needed to win the war against the British Empire. From this, it is clear that money serves as "an instrument of revolution".

The use of money as a symbol of a country's sovereignty has been done in Indonesia since colonial times. The colonial government of the Dutch East Indies as the highest political authority considered that money had a vital role in maintaining the hegemony of colonial power, especially economic hegemony in Indonesia. One of the areas considered necessary in the efforts of the colonial government of the Dutch East Indies to uphold economic sovereignty is the Lampung Residency area.

\section{Independence Revolution}

The era of the physical revolution (1945-1950) was the brightest in Indonesian history. The extraordinary sacrifices demonstrated Indonesia's right to independence by the Indonesian people. The independence revolution was an armed conflict and a diplomatic conflict between the nascent Republic of Indonesia against the Netherlands, assisted by the Allies represented by the British. This series of events occurred from the proclamation of Indonesian independence on August 17, 1945, to the recognition of Indonesia's independence by the Kingdom of the Netherlands on December 29, 1949 [18]-[20].

For about four years, some bloody events occurred sporadically. In addition, there are also political disputes as well as two international interventions. In this event, Dutch forces were only able to control major cities on the islands of Java and Sumatra but failed to take control in villages and suburbs [21][22]. Due to fierce armed resistance and diplomatic struggles, the Dutch were pressured to recognize Indonesia's independence.

The independence revolution was the cornerstone or starting point of the Indonesian revolution. The revolution had significance in Indonesian history, gaining important figures such as Sukarno, Hatta, and Sjahrir. The word revolution has a special meaning in Indonesia. Political, socioeconomic, cultural conditions led to the notion of revolution closely related to independence. There is no independence without revolution and no revolution without independence.

During the physical revolution (1945-1950), Indonesia was in a state of "war emergency" [23]. 
These conditions directly or indirectly affect Indonesian people's social and cultural life during the physical revolution. The instability of social life is emerging in various places in Indonesia. The instability arose as a result of the shock culture experienced by Indonesians after the proclaimed independence.

Sumatra has a population that is not as dense as in Java. The census held by the Dutch East Indies government in 1930 stated that the population of Sumatra was $8,238,570$ people, while the population of Java and Madura was 41,719,5244. During the colonial period, Sumatra saw all foreign powers trying to claim resources in Sumatra. The Dutch governmentbuilt power in Padang, West Sumatra, and the British controlled Bengkulu. American traders monopolized spice exports from Aceh and China-controlled tin in Bangka and Belitung. Oil and coffee are also important commodities in Sumatra.

The Indonesian Independence Revolution, including in Sumatra as part of Indonesia, was rooted in ideas and concepts born during the era of the national movement [21]. Without it, the revolution and proclamation of independence would only be the traditional Ratu Adil movement or robbery movements like the one that erupted in March 1942 when the Dutch surrendered to Japan, and the new invaders had not yet arrived.

Sumatra at the time of the proclamation became a province namely The Province of Sumatra and Medan as the capital, and Mr. Teuku Muhammad Hasan was appointed to hold the position of governor. On April 18, 1946, the Indonesian National Committee of Sumatra convened in Bukittinggi and decided that the Province of Sumatra consisted of three sub-provinces: Sub-Provinces of North Sumatra, Central Sumatra, and South Sumatra. The sub-provinces of Central Sumatra include the Residency of West Sumatra, Riau, and Jambi.

In Lampung itself, the new attack began on January 1, 1949, when the Dutch entered Lampung Bay through Kalianda to Pelabuhan Panjang. Around 5:00 a.m., Dutch warships began firing on the port of Panjang [24]. Dutch troops finally occupied the capital of Lampung Residency on the same day.

\section{RESEARCH METHOD}

This research uses historical methods as the basis of research. The process of this research method includes heuristics, criticism, interpretation, and historiography. Historical methods are used as research methods, especially efforts to suppress subjectivity in research and writing to achieve scientifically tested results [25].

The first stage, heuristics, is the level of resource gathering on the theme to be examined. The sources collected are required following the theme raised. The primary source of this research archives from both De Javasche Bank archives and Bank Indonesia archives. Documents are critical historians in uncovering the past. Documents and archives are vital to historians because, with documents and archives, the past can be carefully reconstructed and displayed as it did in the past. How important Ranke affirms the use of documents and archives is that historians should use primary resources or original resources where they were produced at the time of the event [26]. However, the use of documents and archives is not necessarily usable, historians must be subject to strict supervision, and only "by collecting, criticizing, and verifying all available resources" can historians be in a position to reconstruct the past accurately.

The archives used in this research are located in several places, especially in the Bank Indonesia Archives Collection located at the Bank Indonesia Office. To enrich the data, the archives contained in the National Archives of the Republic of Indonesia (ANRI) the source of this archive is used to obtain a comprehensive overview of the work of Bank Indonesia and its role in Indonesia. In addition, other sources in the form of contemporary newspapers are available in the National Library and several books of reports of President De Javasche Bank.

Secondary sources are various economic history books, world war history, war of independence, articles or translations of articles, and various other official publications that can be used to enrich writing data.

The next stage is criticism, which consists of external criticism and internal criticism, especially in criticism of sources regarding De Javasche Bank until the period of Bank Indonesia. The sources obtained are not processed but done in advance criticism of these sources and re-checked the truth by comparing with other contemporaneous sources.

Internal criticism is used to look at a source's intrinsic value, for example, a year it was published and compare it with other contemporary sources or have the same discussion. This is used to help historians strengthen the validity of a source. While external criticism is used to look at things outside the source's content, such as whether the source is appropriate to the times' situation or whether the source is primary or reproduction.

Then the next stage is interpretation, which is an attempt to analyze and interpret historical facts derived from sources to produce a historical analysis. This analysis is used to obtain a rich horizon in the efforts of historical reconstruction to be written. Interpretation of the sources is made carefully to produce complete writing according to what happened in those days.

The last stage in a historical study is the stage of historiography or history writing. Historiography is done by reconstructing historical events based on the 
findings derived from the sources obtained. Writing is done carefully with the guidance of the sources obtained to avoid any errors or facts that do not correspond to the course of history. This writing is done as the final stage of the historical research stage.

\section{RESULT AND DISCUSSION}

After officially circulating on October 30, 1946, the government of the Republic of Indonesia attempted to distribute the ORI carefully to various regions throughout Java and Madura. The officer put the money in used baskets from the printing press and took it to the train. On the train, the government placed heavily armed officers. The Indonesian government implemented the procedure to ensure the money was free from the interference of the NICA army.

It should be realized that at that time, the Dutch were persistently regaining control of Indonesia. They did everything they could to weaken the Republican position both politically, militarily, and economically. Their strategy also targets the monetary economy. Among other things, by producing a currency known as NICA money or "red money" and preventing ORI circulation to various corners of Indonesia. According to Iskandar [13] "There is an effort by the DutchNICA to destabilize the economy by falsifying ORI and entering and distributing NICA banknotes (red money) to the territory of the Republic of Indonesia".

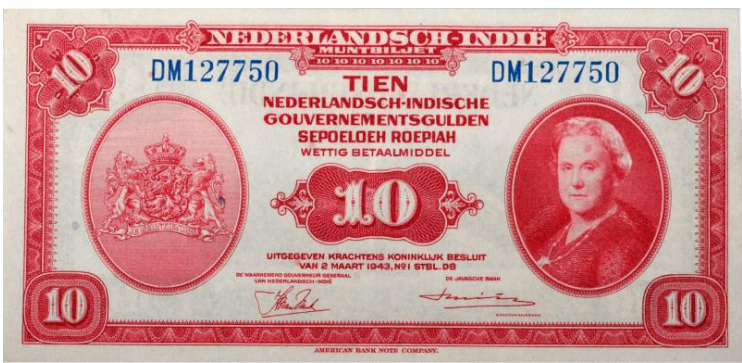

Fig. 1. NICA Banknotes

Source: Museum of Bank Indonesia

With the government's efforts to disseminate ORI money, the community participated in supporting the circulation of ORI in the area of the NICA army. For example, in Cibinong and Bogor, West Java. Here they bet their lives to distribute ORI. The struggle of the people, especially about putting ORI money into the area occupied by the Dutch is still also carried out despite a thousand and one kinds of disturbances, sometimes with torture, murder, and humiliation, as a sign of loyalty to the Government of the Republic [27].

Entering 1947, the situation in several borders of the Republic and the Netherlands heated up. Battles between pro-Republican fighters and soldiers often erupt. ORI distribution is also stuck. Things got worse when the Dutch staged Military Aggression I, which caused the Republic's position in several regions to falter. The Dutch captured several territories of the
Republic. The Renville Treaty reinforced this in January 1948.

Sjafruddin Prawiranegara, the person who proposed that the Indonesian government issue ORI had suspected that the circulation of ORI would not go easy. He said ORI printing was not the end of the struggle. "The exit of Republican Money does not mean that we can later shake our feet and live happily. Even on the contrary, now is the time to work as hard as it is to build regularly and systematically.

Tengku Mohammad Hasan, the governor of Sumatra, proposed to the Minister of Finance to allow him to issue money on a limited basis. "Responding to this request, Sjafruddin proposed that Sumatra print promesse or 'letter of appointment'. However, Hasan has a different view, according to Hasan, banknotes will be much more effective than promesse [28]. After a lengthy discussion, Sjafruddin smoothed Hasan's request. Based on Sumatra Governor Tengku Mohammad Hasan's Information No. 92/K.O, April 8, 1947, the first ORIDA in Indonesia was printed and circulated. ORIDA in Sumatra is known as The Money of Republic of Indonesia Sumatra (ORIPS). The value is equivalent to 1 ORI in Java.

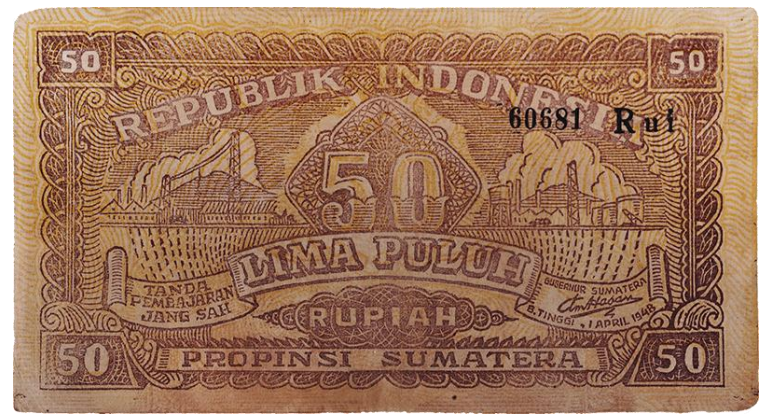

Fig. 2. ORIPS Denomination 50 Rupiah Source: Museum of Bank Indonesia

The Province of Sumatra published the ORIDA as a temporary exchange. ORIDA is domiciled as one of the tools of people's struggle. "The country's fighters fought with weapons and ORIDA accompanied the struggle as a means of exchanging people who refused to use the money issued by the invaders. ORIDA was published and circulated throughout 1947-1950 in Sumatra and Java. Its legality is guaranteed by Government Regulation No. 19/1947, October 26, 1947. This regulation authorizes local governments to issue legitimate temporary currencies or means of payment. The central government also guarantees that all such issuances and the regional currency issued can be exchanged for ORI [28].

\section{A. Regional Initiatives printing money}

When it became difficult to find out that ORI was challenging to circulate in West Java and Sumatra, pro-Republican figures in the area proposed that the 
central government allow them to spend their own money. While awaiting central approval, the Sumatran government took the initiative of printing its own money under the name ORIPS. The first emission was dated April 11, 1947, signed by Governor of Sumatra, Tengku Mohammad Hasan. The issuance of this money is based on the Information of Sumatra Governor Tengku Mohammad Hasan No. 92/K.O. dated April 8, 1947. ORIPS became the first local banknotes in Indonesia. The central government knows and fully supports this publication. The exchange rate is equivalent to 1 ORI in Java. Nevertheless, its circulation was blocked by the NICA army.

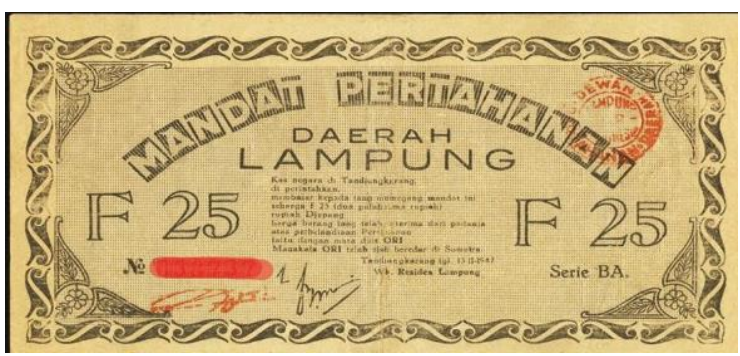

Fig. 3. Local Banknotes 25 Rupiah emission 1947 Source: Lampung Archive Bureau

Dutch military aggression that hit Sumatra and Pematang Siantar made all ORIPS printing activities move to Bukittinggi. Nevertheless, from Bukittinggi, the Republic issued ORIPS for various other regions in Sumatra. "Especially for Bukittinggi emissions, recorded until 1948, there are 13 ORIPS circulated in Sumatra. Entering August 1947, the Asahan government in Sumatra issued a payment instrument in the form of bonds". Bonds can be interpreted as written evidence in a small paper on borrowing a certain amount of money or goods [12].

In response to the issuance of money on the local government's initiative, the central government officially issued Government Regulation No. 19/1947 dated October 26, 1947. Its contents allow provincial, residency, and district governments to publish the local banknotes. "ORIDA is a banknote or valid payment mark that applies on a limited basis in the area [12].

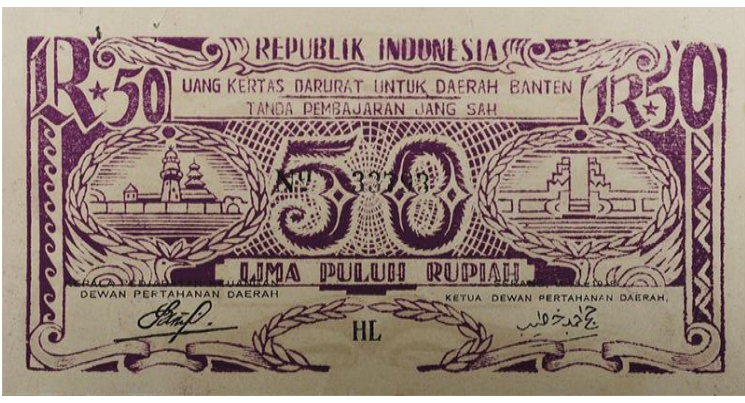

Fig. 4. ORIDAB also Applies in South Lampung Region Source: Museum of Bank Indonesia
ORIDA in Java was first published in Banten on August 11, 1948. This local banknote is circulated with the approval of K. H. Achmad Chatib, Resident of Banten. Its distribution area includes Tangerang, Jasinga (West Java), and South Lampung (Lampung Residency).

Government Regulation No. 19/1947 clarifies the position of local banknotes made by local governments. Therefore, after the regulation came out, the local governments in Java and Sumatra, without hesitation, issued their means of payment. It is not just money there are also forms of bonds, letters of receipt of money, guerrilla coupons, rubber coupons, mandate letters, and payment marks. Call it local currency such as the Money of Republic Indonesia of North Sumatra (URISU), The Money of Republic Indonesia of Tapanuli Region (ORITA), The Money of The Republic of Jambi Region (URIDJA), The Money of the Republic of Indonesia Aceh Region (URIDA), Mandate Money issued by the Regional Defense Counsel of South Sumatra, to The Money of The Republic of Banten (ORIDAB). "ORIDAB is the first ORIDA issued in Java island with Serang emissions published in December 1947 [29].

In Yogyakarta, a Letter of Receipt for The Special Region of Yogyakarta was signed by Sri Sultan Hamengkubuwono IX. The same was published in Surakarta and signed by the Head of The Surakarta Regional Military. In addition to money issued by the government, various community groups also issue payment instruments. As did the Chinese merchant community in Limapuluh Subdistrict, Asahan Regency issues payment instruments with the local government's permission.

Concerning the validity period of ORIDA, the central government issued Government Regulation No. $76 / 1948$ on December 13, 1948, which states that the validity period of ORIDA will be regulated directly by the minister of finance. Mohamad Iskandar noted, there were 21 types of currencies and 27 types of ORIDA until the end of 1949. In war situations, the amount of money in circulation in the territory of the Republic of Indonesia is difficult to calculate precisely. The circulation of ORI and ORIDA amounted to three hundred twenty-three million rupiahs in 1946 and continued to increase to six billion rupiahs at the end of 1949 [30].

ORIDA was published and circulated throughout 1947-1950 in Sumatra and Java. Its legality is guaranteed by Government Regulation (PP) No. 19/1947, October 26, 1947. Pp authorizes local governments to issue legitimate temporary currencies or means of payment. The central government also guarantees that all such issuances and the regional currency issued can be exchanged for ORI. The circulation of ORIPS of Bukittinggi emissions cannot be thorough to Sumatra. The NICA army controlled 
several territories so that other pro-Republican local governments issued their own money as well.

\section{B. Local Banknotes Of Lampung Residency}

The Dutch controlled most of the borders in South Sumatra and blockaded the northern region of Lampung Residency so that Lampung residency was isolated. Tanjung Karang-Telukbetung's relationship with the central government in Yogyakarta was severed. To meet the needs of payment instruments in the Lampung Residency, the central government ordered the Resident of Lampung to print and issue local banknotes.

Local banknotes of Lampung Residency consist of several nominal fractions including $1 / 2,1,21 / 2,5$ and 10 rupiah, Sumatra Province June 1, 1948 and fractions 10 and 50 rupiah Koetabumi, North Lampung, 1949. ORIDA Lampung signed by R. M. Rukadi Wiryoharjo as Resident of Lampung, Basyid Warganegara as vice resident, and Akhmad Akuan as Regent of North Lampung.

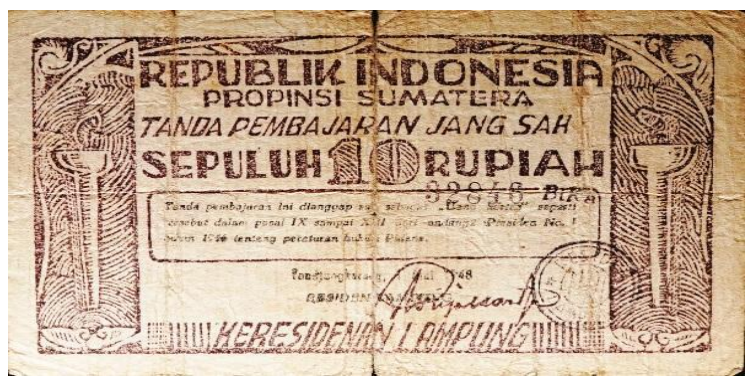

Fig. 5. ORIPS Lampung Residency Emissions 1948 Source: Museum of Bank Indonesia

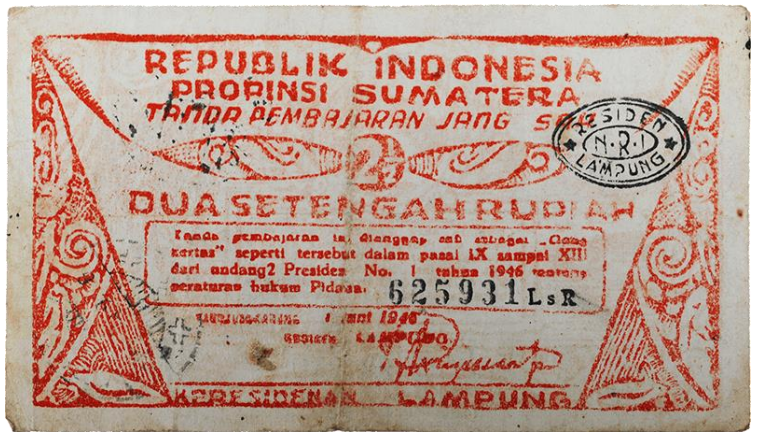

Fig. 6. ORIPS Lampung Residency Emissions 1948 Source: Museum of Bank Indonesia

In addition to printing money Lampung Residency, in the area of Lampung Residency, The Regent of North Lampung which is de facto still not controlled by the Dutch issued money that only applies in the region of North Lampung, also known as "Akuan Money" because Ahmad Akuan signed it as the Regent of North Lampung with a nominal of 50 Rupiah.

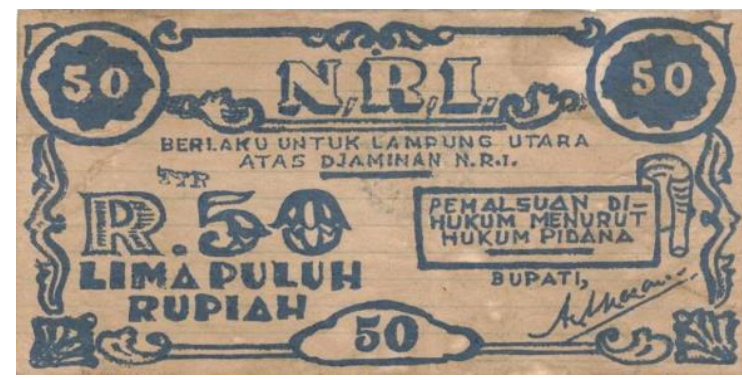

Fig. 7. Kotabumi Banknotes 50 Rupiah signed by Akhmad Akuan Source: Lampung Archive Bureau

In addition to the difficulty of ORI circulation, the issuance of ORIDA is done to finance local government activities. However, according to Sri Margana et al. [29], as with ORI, most of these ORIDA are experiencing severe inflation and a significant decline in value. ORIDA also did not escape forgery. Related to this, Suwito [28], said some weaknesses of ORIDA. "Each area designs itself. Each area does not even know that other areas there are money printing as well. All communication was cut off at that time," said Suwito, some money in Sumatra that had been forged, among others in Pematang Siantar, Kutaraja (Aceh), and Kotabumi (Lampung).

Nevertheless, the issuance of various types of currencies in the form of ORIDA has helped the Republic survive the invasion of NICA money in the region. In addition, the public's acceptance of ORIDA proved the Republic's strong position in various Dutch-occupied areas. The Agreement between Indonesia and the Netherlands through the Round Table Conference in December 1949 ended ORI and ORIDA. The money had to be withdrawn after Indonesia and the Netherlands agreed to issue new money through De Javasche Bank, the central bank of the Dutch East Indies.

After the Round Table Conference was signed, Indonesia changed the form of a state into a federal state. ORI was discontinued in March 1950. It was replaced with new money. Nevertheless, its circulation for three years and five months became the starting point of awareness about the function of money to fight for sovereignty and state financing.

\section{CONCLUSION}

Money in Lampung During the independence revolution served as a means of exchange and symbol of a sovereign state, but more than that, money was also a weapon in the face of economic attacks launched by the Dutch to Indonesia. Various Dutch tactics to destroy Indonesia's economy and monetary, such as blockade and distribution of NICA money, demanded a resistance strategy in the economic and monetary fields, including resistance with money instruments, which was no less heroic in the fight for independence the invaders. People with the spirit and spirit of nationalism that flared up very enthusiastically welcomed the presence of ORI or 
more popularly called "White Money" as the only legitimate means of payment in Indonesia.

Both in the city and the village, all the people proudly used ORI and emphatically refused to use the NICA "Red Money" money as a means of payment. "White Money" was proudly shouted by people all over the Republic of Indonesia at that time. The courage of the people also accompanied the euphoria in overcoming various difficulties to find raw materials and money printing machines and the process of distributing them to various regions amid the increasingly intense Dutch military struggle. The struggle to print and distribute money during the independence revolution was demanding courage and risked the body. Therefore, it is not wrong if the next generation pays high respect while exemplifying the fighters in the economic and financial fields. These fighters have proven the money strategy as one of the instruments of revolution. Money as an instrument of struggle is relevant in the age of revolution and very important for the present and the future.

\section{REFERENCES}

[1] Solikin and Suseno, Uang: Pengertian, Penciptaan, dan Perananannya dalam Perekonomian, Jakarta: Pusat Pendidikan dan Studi Kebanksentralan (PPSK) Bank Indonesia, 2002.

[2] M. Thayeb, "Blokade Ekonomi," Mimbar Indonesia, vol. 1, no. $1,1947$.

[3] E. Simarmata, "Perjuangan Pencetakan ORITA di Kota Sibolga Pada Tahun 1947-1950," Unpublished, Yogjakarta, 2016.

[4] O. B. To, Sejarah Kebijakan Moneter Indonesia Jilid I (19451958), Jakarta: Lembaga Pengembangan Perbankan Indonesia, 1991.

[5] I. Setiawan, Rekonstruksi Birokrasi Pemerintahan Daerah, Bandung: Institut Pemerintahan Dalam Negeri, 2014

[6] H. Nurcholis, Teori dan Praktik Pemerintahan dan Otonom Daerah, Jakarta: Gramedia Widiasarana Indonesia, 2005.

[7] Undang Undang No 22 Tahun 1948.

[8] I. Agusta, Ketimpangan Wilayah dan Kebijakan Penanggulangan di Indonesia: Kajian Isu Strategis, Historis dan Paradigmatis Sejarak Pra Kolonial, Jakarta: Yayasan Pustaka Obor Indonesia, 2014

[9] R. Fitriani, Perjalanan Panjang ORI: Oeang Republik Indonesia, Mata uang yang Lahir Sebagai Alat Revolusi, Bandung: Rosdakarya, 2008

[10] H. Sigalingging et al., Kebijakan Pengedaran Uang di Indonesia, Jakarta: Bank Indonesia, 2005.

[11] Undang Undang No 19 Tahun 1947.

[12] Darsono et al., Berjuang dengan Uang Mempertahankan dan Mamajukan Republik Indonesia: Semangat Juang Otoritas dan Masyarakat Sumatera Utara., Jakarta: Bank Indonesia Institute, 2017.
[13] M. Iskandar, "Oeang Republik," Jurnal Sejarah: Pemikiran, Konstruksi, dan Persepsi, vol. 6, no. 1, 2004.

[14] Yayasan Serangan Umum 1 Maret 1949 \& Perum Peruri Banknotes and Coins From Indonesia 1945-1990, Jakarta Yayasan Serangan Umum 1 Maret 1949 \& Perum Peruri, 1991.

[15] R. Cribb, "Political Dimensions of the Currency Question 1945-1947," Indonesia, vol. 31, no. April 1981.

[16] S. Yoshimasa, "The Monetary Policy in Netherlands East Indies under the Japanesw Administration," Bijdragen tot de Taal, Land, en Volkenkunde, vol. 152, no. 4, pp. 699-724, 1996.

[17] D. Purwoko and S. Shah, Dr. Mr. T. Moehammad Hasan, Salah Seorang Pendiri Republik Indonesia dan Pemimpin Bangsa, Jakarta: Pustaka Sinar Harapan, 1995.

[18] A. Ibrahim, Sejarah Perlawanan Terhadap Imperialisme dan Kolonialisme di Sumatera Selatan, Jakarta: Departemen Pendidikan dan Kebudayaan, 1983.

[19] M. C. Ricklefs, Sejarah Moderen Indonesia, Jakarta: Obor, 2008.

[20] A. K. Pringgodigdo, Sejarah Perjuangan Rakyat Indonesia, Jakarta: Pustaka, 1970

[21] A. Reid, Sumatera: Revolusi dan Elite Tradisional, Jakarta: Komunitas bambu, 2012

[22] R. A. Pratama, "Kecamuk Revolusi Kemerdekaan di Kuningan (1947-1950)," Candrasangkala, vol. 3, no. 2, pp. 217-228, 2018.

[23] R. A. Pratama and M. E. Kamsori, "Mengenai Sutan Akbar pada Masa Revolusi Indonesia di Ciwaru, Kuningan, Jawa Barat Tahun 1947-1948," Susurgalur, vol. 3, no. 2, pp. 217 228,2015

[24] M. G. Harun, Gele Harun Residen Perang Menyelamatkan Kemerdekaan Mmasa Pemerintahan Darurat, Bandar Lampung: Aura Publishing, 2015.

[25] H. Sjamsuddin, Metodologi Sejarah, Yogjakarta: Ombak, 2007.

[26] G. Iggers, The Theory, and Practice of History, London: Routledge, 2010.

[27] H. T. Hanggoro, "Mengenal Oeang Republik Indonesia Daerah (ORIDA)," Historia Id, 9 Oktober 2020. [Online] Available: https://historia.id/ekonomi/articles/mengenaloeang-republik-indonesia-daerah-orida-PebwJ/page/1.

[28] S. Harsono and M. Suharli, ORIDA: Oeang Republik Indonesia Daerah 1947-1949, Jakarta: Gramedia Pustaka Utama, 2020.

[29] S. Margana et al., Keindonesiaan dalam Uang: Sejarah Uang Kertas Indonesia, 1945-1953, Jakarta: Museum Bank Indonesia, 2018.

[30] J. S. Djiwandono, Sejarah Bank Indonesia Periode I : 1945 1959 Bank Indonesia Pada Masa Perjuangan Kemerdekaan, Jakarta: Bank Indonesia, 2005. 